\title{
Petrophysical, petrographic and mineralogical characterization of pre-salt analogue - Purbeck Group, UK
}

Isabela D. de Albuquerque ${ }^{1}$, Silvia L. B. Bermudez ${ }^{1}$, Fabio P. Vieira ${ }^{1}$, Giovanni C. Stael ${ }^{1,2}$, Claudio Rabe $^{3}$, Edmilson H. Rios ${ }^{4}$, Christopher Harper ${ }^{5}$, Alberto André A. S. da Cunha ${ }^{1}$

${ }_{1}^{1}$ Department of Geophysics, National Observatory, São Cristovão, Rio de Janeiro, RJ, Brazil

2 Fluminense Federal University, Praia Vermelha Campus, Rio de Janeiro, Brazil

${ }^{3}$ Baker Hughes, Juana Manso, 205, 4th Floor, Puerto Madero, Buenos Aires, Argentina

${ }^{4}$ Civil Engineering Program, COPPE/Federal University of Rio de Janeiro, Rio de Janeiro, Brazil

${ }^{5}$ Baker Hughes, Stoneywood Park N, Dyce, Aberdeen AB21 7EA, UK

Copyright 2021, SBGf - Sociedade Brasileira de Geofísica

This paper was prepared for presentation during the $17^{\text {th }}$ International Congress of the Brazilian Geophysical Society held in Rio de Janeiro, Brazil, 16-19 August 2021.

Contents of this paper were reviewed by the Technical Committee of the $17^{\text {th }}$ International Congress of the Brazilian Geophysical Society and do not necessarily represent any position of the SBGf, its officers or members. Electronic reproduction or storage of any part of this paper for commercial purposes without the written consent of the Brazilian Geophysical Society is prohibited.

\section{Abstract}

In this work, we characterized mineralogical, petrographic and petrophysically the Mupe Member from the Purbeck Group lower portion, located in southern England and northern France. These rocks mainly consist of limestones and can be considered as a partial analogue rock of the Brazilian pre-salt carbonate reservoirs.

The laboratory tests campaign to characterize there lithologies comprised of X-ray diffraction (XRD) tests and thin sections description, gas effective porosity and absolute permeability, nuclear magnetic resonance (NMR).

The results of XRD and thin sections indicated a mineralogy rich in low-magnesium calcite and the presence of different types of pores. The NMR $\mathrm{T}_{2}$ distribution indicated that the plugs are very heterogeneous, having pore size distributions varying from bimodal to polymodal.

\section{Introduction}

The production of oil and gas from the Brazilian pre-salt is significant, accounting for over $70 \%$ of the national production (ANP, 2021). The pre-salt reservoir rocks are composed mainly of carbonates and present variable properties due to spatial heterogeneities.

In carbonate rocks, the generation of pore space networks and permeability evolution are strongly associated with complex physical chemical processes such as dissolution and precipitation reactions. They can induce the generation of secondary porosity due to the higher solubility of calcareous minerals, forming a complex pore structure in these rocks (Bagrintseva, 2015; Tiab e Donaldson, 2015).

It is of extreme importance to quantitatively determine the reservoir's petrophysical characteristics through laboratorial core analysis (McPhee et al., 2015). However, due to the high cost for obtaining rock cores samples from offset wells, especially in deepwater wells, the usage of analogue reservoir rocks is common practice in the oil and gas industry.

The Mupe Member, composed of Upper Jurassic lacustrine microbialites, and associated facies formed in a semi-arid climate setting in an extensional basin, can be considered as a partial analogue for some aspects of the Brazilian pre-salt carbonate reservoirs. The deposits are approximately the same age, have a similar tectonic setting and basin evolution processes (both are pre-salt) and both have porous microbial mound facies" (Gallois \& Bosence, 2017).

In this work, we characterized the mineralogy and petrography of the Mupe Member carbonates through Xray diffraction (XRD) and thin sections, respectively. Routine core analysis (RCAL), including effective gas porosity and absolute permeability, and nuclear magnetic resonance (NMR) were used for the petrophysical analysis.

\section{Method}

From the blocks available for this study, two samples were selected to be analyzed by:

- X-ray diffraction (XRD) at the Mineral Technology Center (CETEM) at the Ministry of Science, Technology and Innovation using the D4 Endeavor equipment manufactured by Bruker-AXS. The Rietveld Method (Rietveld, 2014) was used to characterize the crystalline phases present;

- and two petrographic thin sections were made from two representative facies and described at the Geological Sample Processing Laboratory (LGPA) at the State University of Rio de Janeiro (UERJ).

Six plugs, with 1.5 inches in diameter (about $3.8 \mathrm{~cm}$ ) and between 2 and 2.6 inches (about 5 to $6.7 \mathrm{~cm}$ ) in length, were cored from three blocks (1,3 and 6) with different facies identified visually.

Plugs were cleaned using the standard Hot Soxhlet extraction method with toluene and methanol circulation for removal of residual oil and salts contained in the pore spaces - these were then dried in an oven. 
The plugs were then analyzed using the following methods and equipment:

- Helium effective porosity and nitrogen absolute permeability using the gas porosimeter and permeameter model DV-4000, manufactured by Stratum Reservoir (Previous Weatherford Labs), available at the Enhanced Oil Recovery Laboratory (LRAP) at UFRJ;

- Nuclear magnetic resonance (NMR), for liquid-filled porosity and transverse relaxation time $\left(T_{2}\right)$ measurements. The laboratory tests were conducted using the Maran $12 \mathrm{MHz}$ equipment manufactured by Oxford Instruments, available at the Geophysics and Petrophysics Laboratory (LAGEP) at UFRJ.

- Pressure saturation. For the NMR analysis, the samples were saturated at $1,000 \mathrm{psi}$ of pressure with distilled water using the sample saturator from the manufacturer Vince instruments, available at the National Observatory's Petrophysics Laboratory (LabPetrON) and then weighed to verify the effectiveness of the saturation procedure. The saturation index was calculated from the following equations:

$$
\begin{aligned}
& V_{\text {fluid }}=M_{\text {saturated }}-M_{\text {dry }} \times \text { pfluid, } \\
& \text { Saturation index }=V_{\text {fluid }} / V_{\text {pores }}
\end{aligned}
$$

where $V_{\text {fluid }}$ is the volume of fluid saturating the porous space of the rock, $M_{\text {saturated }}$ is the mass of the saturated sample, $M_{\text {dry }}$ is the dry mass of the sample, Pfluid is the saturating fluid density and $V_{p}$ is the helium-measured pore volume.

\section{Results}

XRD results are presented in Table 1. They indicate that the samples are composed almost entirely of lowmagnesium calcite, with smaller quantities of quartz and barite.

\begin{tabular}{|c|c|c|}
\hline & Sample 1 & Sample 2 \\
\hline Phase Name & Wt\% Rietveld & Wt\% Rietveld \\
\hline Quartz & 3.5 & 0.6 \\
\hline Magnesian Calcite & 96.5 & 98.4 \\
\hline Barite & 0 & 1 \\
\hline Total & 100 & 100 \\
\hline Mg in calcite & 0.001 & 0 \\
\hline
\end{tabular}

Table 1. XRD results.

In thin section 1 (facies similar to plugs $1 \mathrm{X}$ and $3 \mathrm{Y}$ ), it was observed that the sample is rich in micritic matrix material with what Gallois (2016) interpreted as sparse chalcedony spherules, resulting from recrystallisation of the micritic matrix (Figure 1). In porous zones, sparry calcite has crystallized, probably due to the passage of calcitic fluid during burial (Figure 5). The carbonate rock can be classified as a mudstone to wackestone, according to the Dunham (1962) classification methodology. The main porosity types observed are vugular, intergranular, moldic and microporosity.
Thin section 2 (facies similar to plugs $3 Z, 6 \mathrm{X}, 6 \mathrm{Y}$ and $6 \mathrm{Z}$ ) presents a branched columnar stromatolitic structure made of pelloids, chalcedony spherules and micrite matrix vertically stacked with poorly marked laminations (Figure 6), occurring laterally with zones rich in peloids and sparry calcite cement. The sample also presents sparry calcite crystallized in the pore walls. The rock can be classified as a thrombolite to stromatolite, according to the Aitken (1967) classification methodology. The main porosity types observed are vugular, intergranular, growthframework and microporosity. (a)

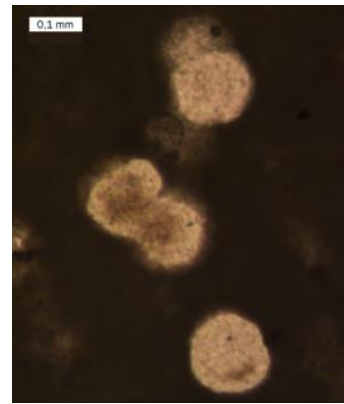

(b)

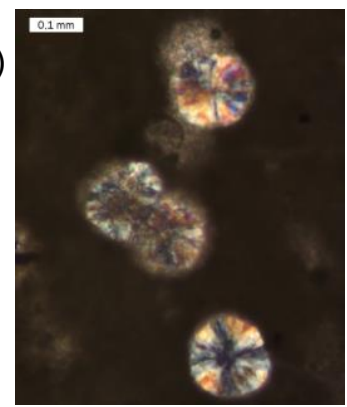

Figure 1. (a) Brownish nodular crystals under natural light and (b) radial extinction cross under polarized light in thin section 1 , with a $10 x$ magnification.

The results of tests on gas porosity and permeability, samples saturation index and porosity obtained by NMR are presented in Table 2, the comparison between the porosity results are shown in Figure $\mathbf{2}$ and the comparison between gas porosity and permeability are shown in Figure 3. The correlation between the different results was very satisfactory, demonstrated by the high coefficient of determination $\mathrm{R}^{2}=0.96$.

Table 2. Gas porosity and permeability, saturation index and porosity obtained by NMR.

\begin{tabular}{|c|c|c|c|c|} 
Sample & $\begin{array}{c}\text { Gas } \\
\text { porosity } \\
(\%)\end{array}$ & $\begin{array}{c}\text { Gas } \\
\text { permeability } \\
(\mathbf{m D})\end{array}$ & $\begin{array}{c}\text { Saturation } \\
\text { index } \\
(\%)\end{array}$ & $\begin{array}{c}\text { NMR } \\
\text { porosity } \\
(\%)\end{array}$ \\
\hline $\mathbf{1 X}$ & 12.10 & 1820.53 & 84.09 & 11.48 \\
\hline $\mathbf{3 Y}$ & 12.50 & 1868.37 & 74.24 & 11.04 \\
\hline $\mathbf{3 Z}$ & 6.60 & 4.28 & 82.72 & 6.17 \\
\hline $\mathbf{6 X}$ & 6.40 & 0.26 & 94.85 & 7.11 \\
\hline $\mathbf{6 Y}$ & 8.14 & 0.83 & 91.22 & 8.34 \\
\hline $\mathbf{6 Z}$ & 7.62 & 2.13 & 93.9 & 7.54 \\
\hline
\end{tabular}

Based on gas porosity and permeability results, the analyzed plugs can be separated into two groups (Figure 3): with higher porosity and extremely high permeability values (samples $1 \mathrm{X}$ and $3 \mathrm{Y}$ ) and with lower porosity and low permeability values (samples $3 Z, 6 \mathrm{X}, 6 \mathrm{Y}$ and $6 \mathrm{Z}$ ).

The saturation values were satisfactory for plugs $6 \mathrm{X}, 6 \mathrm{Y}$ and $6 Z$ and low for samples $1 X, 3 Y$ and $3 Z$. The low values of saturation are likely due to the large number of vugular pores, which can decrease the effectiveness of the saturation process because they fail to retain the saturation fluid (De Luna et al., 2016). 


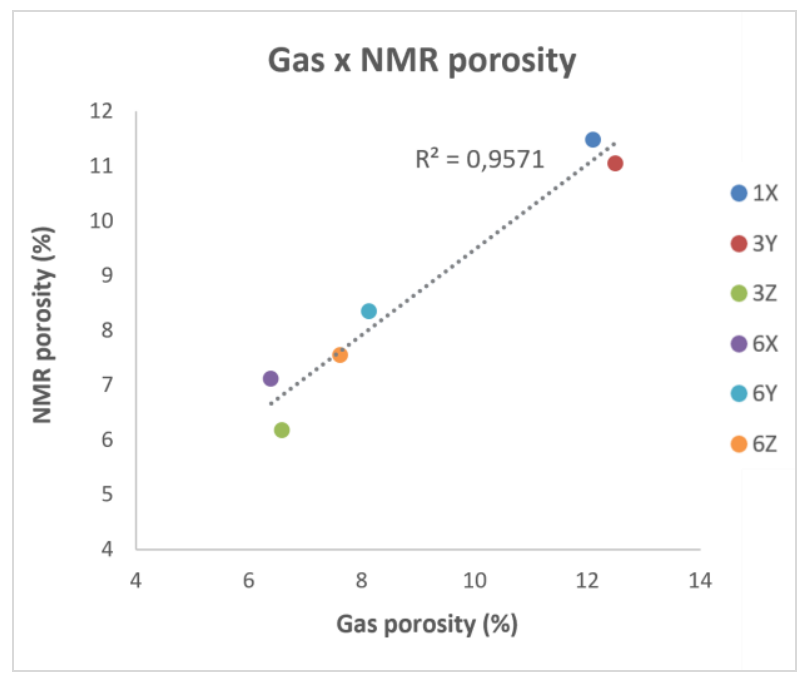

Figure 2. Correlation between helium porosity and NMR porosity.

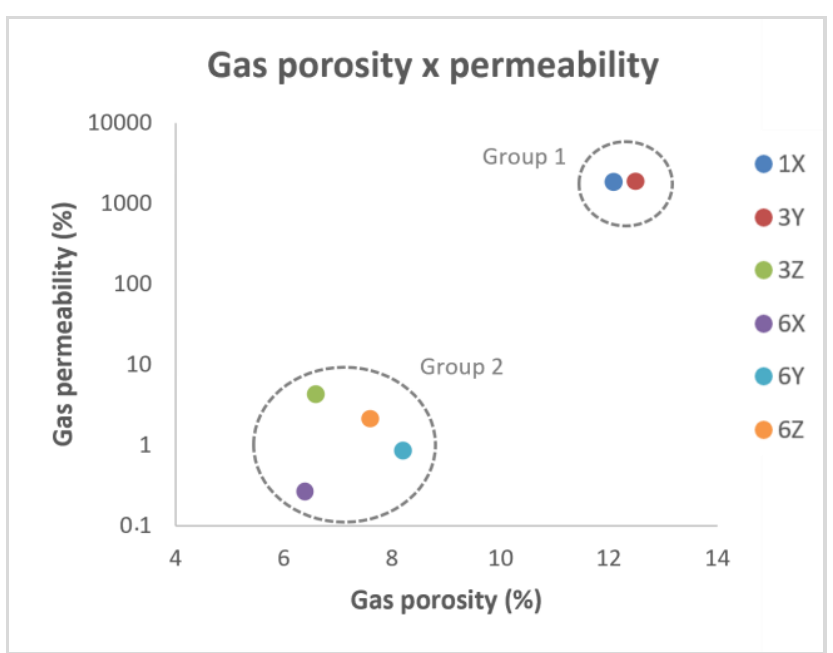

Figure 3. Correlation between gas porosity and gas permeability.

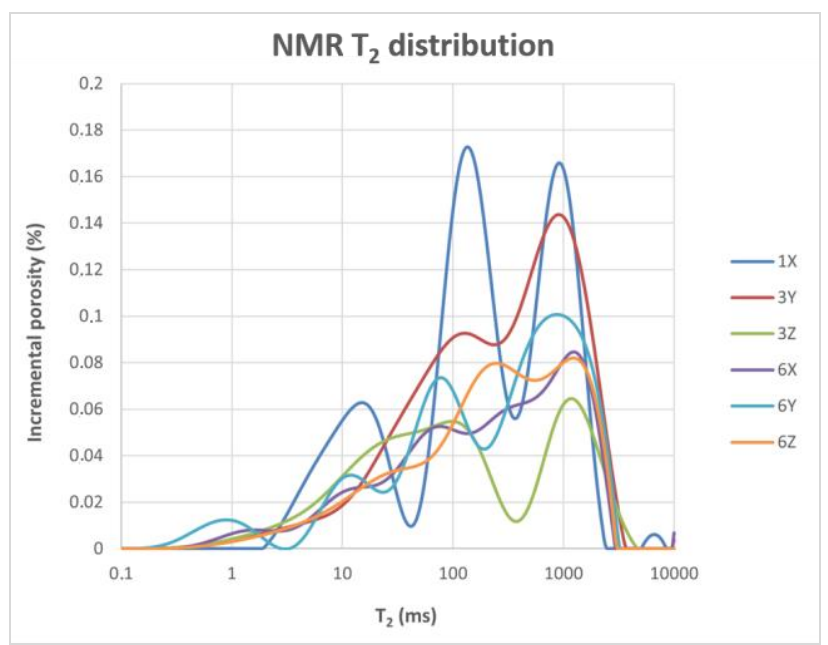

Figure 4. NMR $T_{2}$ distribution.

\section{Conclusions}

The results of $\mathrm{XRD}$ analysis and the description of the petrographic thin sections indicated that the mineralogy is rich in low-Mg calcite and also indicates the presence of different types of pores. Different facies were recognized having similar mineralogy but with different porosity and vastly different permeability characteristics.

Gas porosity and permeability results indicated two groups: with higher porosity and extremely high permeability values (samples $1 \mathrm{X}$ and $3 \mathrm{Y}$ ) and with lower porosity and low permeability values (samples $3 Z, 6 X, 6 Y$ and $6 \mathrm{Z})$.

Despite the low saturation values for the samples with vugular pores (samples $1 \mathrm{X}, 3 \mathrm{Y}$ and $3 \mathrm{Z}$ ), the porosity results obtained by routine core analysis and by NMR for all samples indicated a good correlation.

The $T_{2}$ distribution results indicate that the plugs are very heterogeneous, having pore size distributions varying from bimodal to polymodal.

\section{Acknowledgments}

We thank Baker Hughes for donating the samples analyzed, the teams of the National Observatory's Petrophysics Laboratory (LabPetrON), the Enhanced Oil Recovery Laboratory (LRAP) at the Federal University of Rio de Janeiro (UFRJ), the Geophysics and Petrophysics Laboratory (LAGEP) at UFRJ, the Mineral Technology Center (CETEM) at the Ministry of Science, Technology and Innovation, and the Geological Sample Processing Laboratory (LGPA) at the State University of Rio de Janeiro (UERJ) for the support with the samples analysis and the National Council for Scientific and Technological Development (CNPq) for the financial support.

E.H.R. would also like to add that part of this research was carried out in association with the ongoing R\&D project registered as ANP n 20163-2, "Análise Experimental da Recuperação de Petróleo para os Carbonatos do Pré-sal do Brasil através de Injeção Alternada de $\mathrm{CO}_{2}$ e Água" (UFRJ/Shell Brasil/ANP), sponsored by Shell Brasil under the ANP R\&D levy as "Compromisso de Investimentos com Pesquisa e Desenvolvimento".

\section{References}

AITKEN, James D. Classification and environmental significance of cryptalgal limestones and dolomites, with illustrations from the Cambrian and Ordovician of southwestern Alberta. Journal of Sedimentary Research, v. 37, n. 4, p. 1163-1178, 1967.

ANP. Boletim Mensal da Produção de Petróleo e Gás Natural. Março, 2021.

BAGRINTSEVA, Ksenia I. Carbonate reservoir rocks. John Wiley \& Sons, 2015.

DE LUNA, José Leão et al. Petrophysical rock typing of Coquinas from the Morro do Chaves Formation, SergipeAlagoas Basin (Northeast Brazil). Brazilian Journal of Geophysics, v. 34, n. 4, p. 509-521, 2016. 
GALLOIS, A.; BOSENCE, D. Syn-rift lacustrine carbonates; cycles, microbial mounds, and brackish to hypersaline facies models; Purbeck Group, Wessex Basin, UK. Analogues for south Atlantic pre-salt carbonates?. Conference on African E\&P, 2017.

HOERLLE, Fernanda Oliveira et al. Nuclear magnetic resonance to characterize the pore system of coquinas from Morro do Chaves Formation, Sergipe-Alagoas basin, Brazil. Brazilian Journal of Geophysics, 2018.
MCPHEE, Colin; REED, Jules; ZUBIZARRETA, Izaskun. Core analysis: a best practice guide. Elsevier, 2015.

RIETVELD, Hugo M. The rietveld method. Physica Scripta, v. 89, n. 9, p. 098002, 2014.

TIAB, Djebbar; DONALDSON, Erle C. Petrophysics: theory and practice of measuring reservoir rock and fluid transport properties. Gulf professional publishing, 2015.

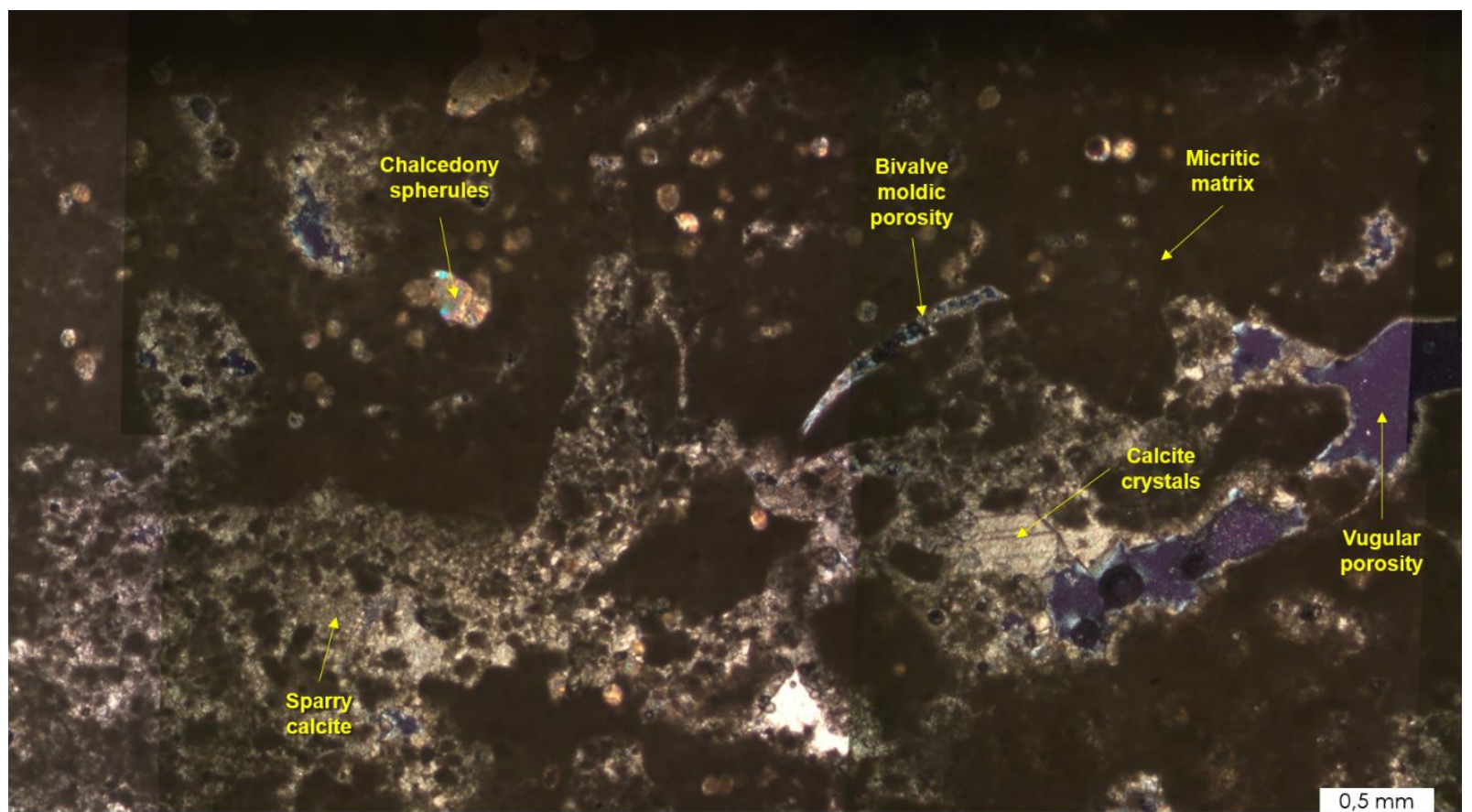

Figure 5. Thin section 1, highlighting the parts rich in micritic matrix with sparse chalcedony spherules and the porous regions with sparry calcite with well-formed calcite crystals on the walls of the vugular pores, in addition to the presence of moldic pores generated by the dissolution of fossil shell (likely bivalve).

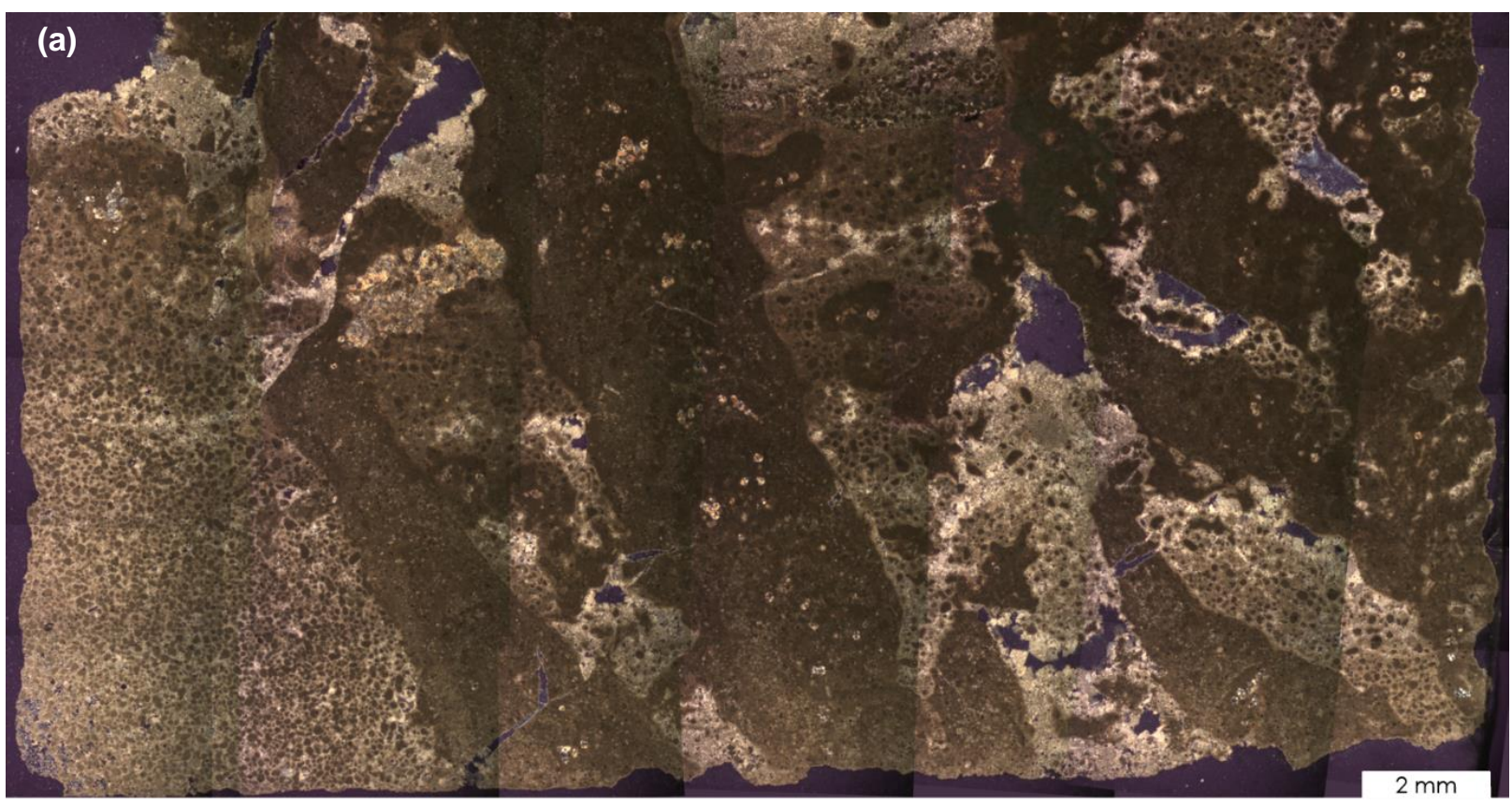




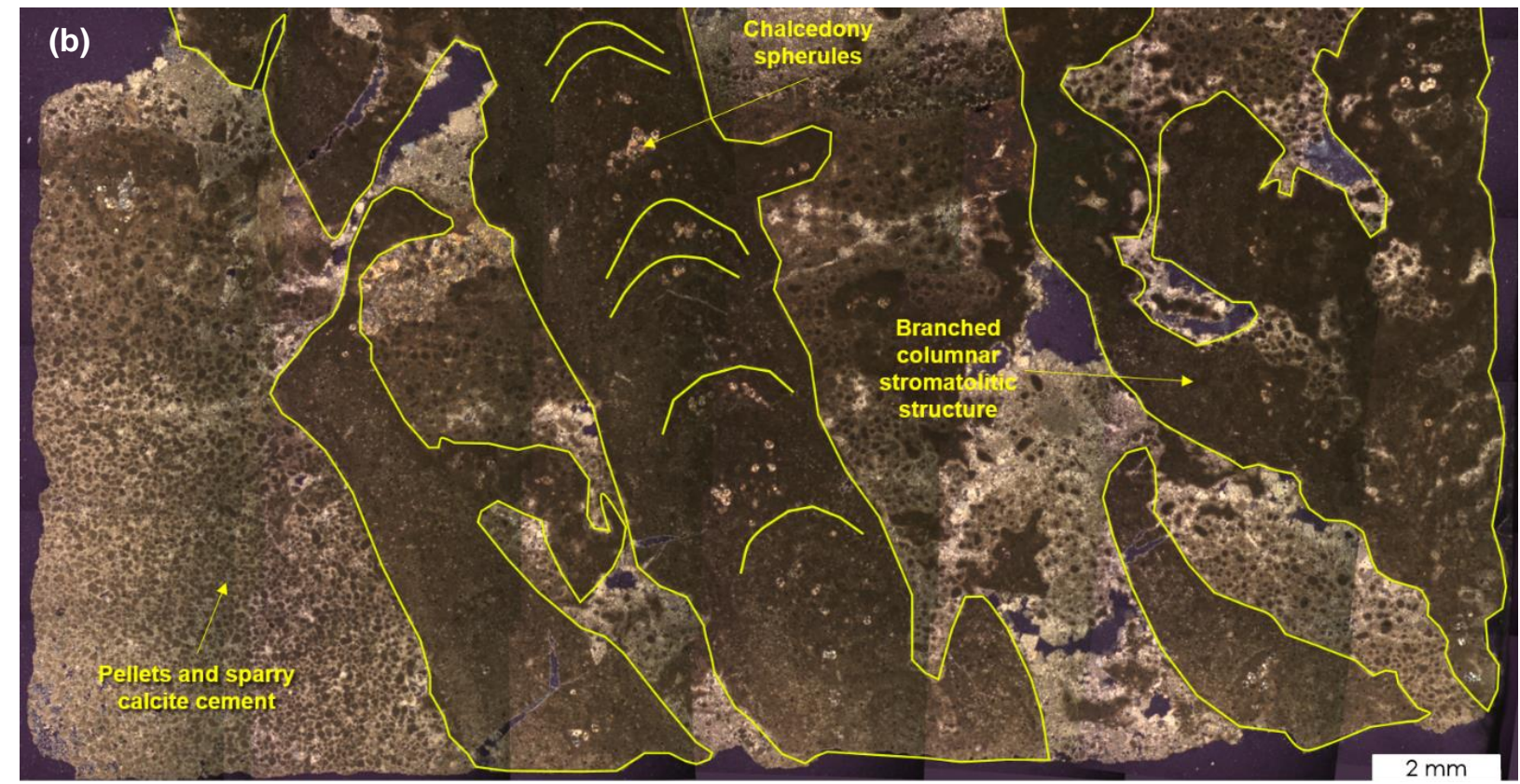

Figure 6. (a) Thin section 2 and (b) the same image highlighting the branched columnar stromatolitic structure with poorly marked laminations. 